\title{
Identifying Important Skills and Competencies Needed for New Florida Agriculture Extension Agents
}

\author{
A. Halbritter ${ }^{1}$, M. Wallau², M. Benge ${ }^{3}$, C. Mackowiak ${ }^{4}$
}

\section{Abstract}

The onboarding needs of Extension agents is a topic continuously discussed and researched, yet overwhelmed agents persist, suggesting that there is still a missing link. We undertook a study to determine the competency training needs of newly hired agricultural agents in Florida. Two assessments were performed. First, we asked University of Florida's County Extension agents and Directors in Agriculture, Horticulture and Natural Resources to identify main agriculture skills and competencies for new Extension. Second, we then classified those competencies into main domains and asked the same cohort to rank the competencies within each domain, in order of most important to least important. Data were collected via an online surveys, with $65 \%$ and $51 \%$ response rates, respectively. Agents needed training in specific agricultural competencies related to every-day work activities such as soil sampling, diagnostic skills, educational resource utilization, and relationship building. Although we assume that, based on job requirements, newly hired agents will enter Extension with such knowledge, results suggest an agriculture specific training is needed to meet the onboarding needs of new agents. Our study identified the priority needs for developing an onboarding program that establishes a level of standard knowledge. Those findings will serve to enhance onboarding training for new Extension professionals.

\section{Keywords}

Professional development, needs assessment, basic skills, in-service training, onboarding

1. Alicia Halbritter, Agriculture and Natural Resources Extension Agent I, University of Florida, 1025 W. Macclenny Ave, Macclenny, FL 32603, aliciah1221@ufl.edu, iD https://orcid.org/0000-0002-2991-0871

2. Marcelo Wallau, Assistant Professor and Forage Extension Specialist, University of Florida, PO Box 110965, mwallau@ufl.edu, (D) https://orcid.org/0000-0001-9898-3399

3. Matt Benge, Extension Assistant Professor, University of Florida, PO Box 112060, mattbenge@ufl.edu, (iD) https://orcid.org/0000-0002-5358-3233

4. Cheryl Mackowiak, Associate Professor, University of Florida, 155 Research Rd, Quincy, FL 32610, echo13@ufl.edu, 


\section{Introduction and Problem Statement}

Agriculture plays a pivotal role in Florida's economy as the second highest grossing industry (Florida Department of Agriculture and Consumer Services [FDACS], 2019). Florida's vast and diverse agriculture industry presents a challenge for Extension agents to be prepared and equipped (Cooper \& Graham, 2001; Harder et al., 2010; Seevers \& Graham, 2012) to work with and educate stakeholders with the most current best management practices and unbiased information. Entry-level Extension agents often feel overwhelmed with the diverse requirements of their jobs (Arnold \& Place, 2010). Supporting those early stages through the development of job-related skills can be fundamental for career success (Bailey, 2005). Appropriate initial training can significantly impact behavior, attitudes, practices, and relationships, leading to a more productive and less stressful early career. Nevertheless, the diverse professional and educational backgrounds of newly hired agents, coupled with the wide variety of clientele demands, makes defining onboarding educational needs a challenge. Thus, it is important to understand what agents perceive are the main skills needed for early-career peers to be successful in their jobs. This information can help develop more efficient onboarding trainings to fulfill immediate needs and challenges newly hired Extension agents face when joining our institution.

\section{Theoretical and Conceptual Framework}

Agriculture Extension agents need to be competent in agricultural practices and have technical/subject matter expertise early in their career to be successful. McClelland (1973) suggested that competency approach was a better approach to employee and organizational success than an intelligence or trait approach. Harder et al. (2010) further advocated for a competency approach within Cooperative Extension, stating "the implications of the competency approach for organizational development are clear; organizations that identify the skills, knowledge, and abilities needed to achieve their goals, and work to develop those competencies in their employees through training and education, will achieve increased capacity" (p. 45).

Harder et al. (2010) identified technical/subject matter expertise as one of nineteen important competencies entry-level Extension professionals' need. Furthermore, the Extension Professional Development Model supports the notion that technical/subject matter expertise should be possessed by Extension agents upon entering the organization; and the Extension organization should provide professional development and training to extension agents prior to starting the job if they are lacking skillsets (Benge et al., 2011; Brown et al., 2008; Gusto et al., 2020; Moore \& Rudd, 2004). Specifically, regarding technical/subject matter expertise, there is some literature citing the needs for agriculture-related competencies for Extension agents, such as integrated pest management (Benge et al., 2020), produce safety (Kilonzo-Nthenge et al., 2018), tree and forest health (Gusto et al., 2020), aquaculture (Schwarz \& Gibson, 2010), and nematology (Gentry et al., 2017). However, the literature is limited in understanding the skills and competencies new agriculture Extension agents should possess early in their career. 
In Florida, the Extension Faculty Development Academy (EFDA) provides foundational training to new Extension agents and specialists, focusing on program development, program evaluation, teaching and learning, and communication. However, there was not technical/subject matter training for new agriculture Extension agents. Two of the researchers were commissioned by the Associate Dean for Extension, Agricultural and Natural Resources Programs to address this need. In order to begin developing an onboarding process that incorporates agricultural skills, we created a needs assessment to determine the main skills and competencies perceived as important for those early-career stages.

\section{Purpose}

The purpose of our study was to understand the skills and competencies needed by early career agriculture Florida Extension agents. Our objectives were to

1. Identify the agriculture-related competencies needed by early-career agriculture Extension agents, and

2. Describe Florida agents' perceptions of the importance of agriculture skills and competencies needed for early-career agriculture Extension agents.

\section{Methods}

We used an exploratory sequential design with a mixed methods approach (Creswell \& Plano Clark, 2018) which allows us to identify and assess needs of our audience with limited understanding or previous research available (Witkin \& Altschuld, 1995). First, through qualitative research, we identified the main agriculture skills and competencies for new agriculture Extension which were then ordered (quantitative step) by perceived rank of importance. We targeted Florida agriculture Extension agents and County Extension Directors (CEDs) to participate in our study. County Extension Directors are expected to have a good understanding of all areas of Extension, as well as the firsthand challenges experienced by new agriculture faculty, which is why we included them in the study. Two questionnaires were developed and administered online through Qualtrics, during the summer of 2019 and spring 2020. Institutional Review Board approval was obtained prior to conducting the study. The first questionnaire consisted of the open-ended question, "In your opinion, what types of skills do new agriculture/horticulture agents need when they begin their job as an Extension agent. We also included five demographic questions related to their years of experience, if they were a CED, highest degree completed, formal education background, and their major programmatic area (i.e. agriculture, horticulture, or livestock/forage). We asked a 4-member expert panel comprising three state Extension specialists and one Extension agent to review the study (Ary et al., 2006). The Tailored Design Method (Dillman et al., 2009) was used to ask Extension agents and CEDs $(n=190)$ to complete the survey, yielding 124 complete responses and a $65 \%$ response rate.

Through a constant comparative method (Merriam, 1998) we conducted the analysis of the first survey, reducing the data into identifiable, recurring themes (Lincoln \& Guba, 1985). Within qualitative research it is important to address trustworthiness (Lincoln \& Guba, 1985). We 
maintained an audit trail throughout the data sorting and analysis steps and used investigator triangulation (Patton, 1999) to interpret the data collaboratively. Researchers were three state Extension specialists of different subject matters (i.e., Agronomy, Soils and Education) and one county agent, who are responsible for onboarding. A pilot test to verify reliability of the data was not conducted. Our analysis yielded four competency domains which we incorporated into our second questionnaire.

Our second questionnaire described the importance of the agriculture skills and competencies needed for early-career agricultural agents. Again, we asked both agriculture Extension agents and CEDs ( $n=194$ ) to complete the survey, yielding 98 complete responses and a $51 \%$ response rate. We asked respondents to rank the competencies within each domain in order of most important to least important. For example, for the agriculture-related domain, "Please rank the below agriculture-related skills in order of importance (1 = most important and $13=$ least important) for new agriculture Extension agent success. To rank, simply click on the item and move it to the rank you desire." We created an average ranking within each competency domain, with the highest ranking (i.e. lowest 'score') representing the competency which was most important to respondents.

Respondents' demographic characteristics are presented in Table 1 (see Table 1). All questions were completed in all responses submitted, minimizing non-response error. The average respondent was an Extension agent with 0-5 years of experience, and held a Master's degree in horticultural science.

\section{Table 1}

Demographic Characteristics of Survey Respondents

\begin{tabular}{llcc}
\hline Demographic characteristic & & $f$ & $\%$ \\
\hline Years working in extension & $0-5$ & 47 & 37.9 \\
& $6-10$ & 18 & 14.5 \\
& $11-15$ & 24 & 19.4 \\
& 16 or more & 35 & 28.2 \\
\hline County Extension director & Yes & 38 & 30.6 \\
& No & 86 & 69.4 \\
\hline Highest degree completed & Bachelor's & 9 & 7.3 \\
& Master's & 96 & 77.4 \\
& Doctorate & 19 & 15.3 \\
\hline Formal educational background & Horticultural science & 32 & 25.8 \\
& Animal science & 24 & 19.4 \\
& Agronomy & 18 & 14.5 \\
& Agriculture education & 12 & 9.7 \\
& Natural resources & 9 & 7.3 \\
& Agriculture business & 6 & 4.8 \\
& Biology & 6 & 4.8 \\
& Pest \& diseases & 6 & 4.8 \\
& Other/no response & 11 & 8.9 \\
\hline
\end{tabular}




\section{Findings}

Twenty-four distinct competencies were identified and categorized into four major competency domains of agriculture, extension-related, technical resources, and personal relationships (see Table 2).

\section{Table 2}

List of Competency Domains and Competencies deemed Important by Respondents

\begin{tabular}{|c|c|}
\hline Competency domain & Specific competencies \\
\hline Agriculture & $\begin{array}{l}\text { Soil properties and sampling; plant identification; diagnostic } \\
\text { sample submission and interpreting results; plant } \\
\text { physiology/horticulture/agronomic practices; disease diagnostics; } \\
\text { insect identification; fertilizer management; pesticides; livestock } \\
\text { husbandry/management; pasture management; irrigation; } \\
\text { industry economics; natural resources. }\end{array}$ \\
\hline Extension-related & $\begin{array}{l}\text { Customer service; public speaking and presenting; organization } \\
\text { and time management; communicating with a diverse audience; } \\
\text { written communication; program planning; program evaluation; } \\
\text { educational technology; conflict resolution; social media. }\end{array}$ \\
\hline Technical resources & $\begin{array}{l}\text { Specialists; EDIS; diagnostic labs; accessing critical/scientific } \\
\text { information; Florida research and education centers; } \\
\text { administration; agencies and stakeholders outside of extension. }\end{array}$ \\
\hline Personal relationships & $\begin{array}{l}\text { Clientele; agent to agent; County Extension directors; Extension } \\
\text { specialists and researchers. }\end{array}$ \\
\hline
\end{tabular}

Extension-related competency domain skills were included in the majority $(60.5 \%)$ of the responses of the first survey. When asked to rank competencies, respondents perceived customer service skills, public speaking/presentation skills, and organization/time management the most important competencies for new agriculture Extension agents (see Table 3). Social media, conflict resolution, and educational technology were ranked least important. 


\section{Table 3}

Ranking of Important Competencies from the Extension-Related Domain

\begin{tabular}{lcc}
\hline Competency & $\begin{array}{c}\text { Ranking of } \\
\text { importance }\end{array}$ & $\begin{array}{c}\text { Average } \\
\text { ranking }\end{array}$ \\
\hline Customer service skills & 1 & 2.90 \\
Public speaking/presentation skills & 2 & 3.78 \\
Organization/time management & 3 & 4.24 \\
Communicating with a diverse audience & 4 & 4.68 \\
Written communication & 5 & 5.02 \\
Program Planning & 6 & 5.07 \\
Program evaluation & 7 & 6.09 \\
Educational technology & 8 & 6.70 \\
Conflict resolution & 9 & 8.09 \\
Social media & 10 & 8.43 \\
\hline
\end{tabular}

Fifty-eight percent of the respondents of the original survey included agriculture competency domain as main skills need for new agriculture Extension agents. When asked to rank, respondents perceived soil properties and sampling, plant identification, and diagnostic sample submission and interpreting results the most important competencies for new agriculture Extension agents (see Table 4). Natural resources, industry economics, and irrigation were ranked least important.

\section{Table 4}

Ranking of Important Competencies from the Agriculture Domain

\begin{tabular}{lcc}
\hline Competency & $\begin{array}{c}\text { Ranking of } \\
\text { importance }\end{array}$ & $\begin{array}{c}\text { Average } \\
\text { ranking }\end{array}$ \\
\hline Soil properties \& sampling & 1 & 4.43 \\
Plant identification & 2 & 5.10 \\
Diagnostic sample submission \& interpreting results & 3 & 5.16 \\
Plant physiology/horticulture/agronomic practices & 4 & 5.60 \\
Disease diagnostics & 5 & 6.06 \\
Insect identification & 6 & 6.07 \\
Fertilizer management & 7 & 6.51 \\
Pesticides & 8 & 6.60 \\
Livestock husbandry/management & 9 & 8.53 \\
Pasture management & 10 & 8.78 \\
Irrigation & 11 & 9.01 \\
Industry economics & 12 & 9.36 \\
Natural resources & 13 & 9.78 \\
\hline
\end{tabular}


Both the Agriculture and Extension-Related competency domains demonstrate few subcategories that are prioritized higher than others by a larger number of respondents. General knowledge, like soil properties and horticulture/agronomic practices, were ranked with a higher priority than application-oriented skills like pasture management, fertilizer management, or irrigation. The former group has a broader application over most agriculture program areas (i.e. natural resources, horticulture, crops, etc.) while application-oriented skills are applicable to a lesser range of agents and therefore not as important for a general onboarding process. This indicates that onboarding for agriculture Extension agents likely needs to have two tiers: (a) a broad and general training composed of skills needed regardless of the job specifics; and (b) a second more program-area oriented section to cover the managementrelated topics. Condensing onboarding for agents according to this strategy has the potential to reduce the staff development effort and expense required to establish necessary competencies in all new hires.

Regarding the Technical Resources domain (20.2\% of original responses), respondents perceived specialists, extension factsheets (Electronic Data Information Source, EDIS), and diagnostic labs the most important resources for new agriculture Extension agents (see Table 5). Administration and agencies/stakeholders outside of Extension were ranked least important for new agriculture Extension agents.

\section{Table 5}

Ranking of Important Resources from the Technical Domain

\begin{tabular}{lcc}
\hline Competency & $\begin{array}{c}\text { Ranking of } \\
\text { importance }\end{array}$ & $\begin{array}{c}\text { Average } \\
\text { ranking }\end{array}$ \\
\hline Specialists & 1 & 2.42 \\
Extension factsheets (EDIS) & 2 & 3.78 \\
Diagnostic Labs & 3 & 3.80 \\
Accessing critical/scientific information & 4 & 4.15 \\
Research \& Education Centers & 5 & 4.31 \\
Administration (CED/DED/Program Leaders) & 6 & 4.48 \\
Agencies/stakeholders outside of Extension & 7 & 5.06 \\
\hline
\end{tabular}

Last, on the Agent Relationships domain (23.5\% of original responses), respondents perceived clientele and agent relationships as the most important relational contacts for new agriculture Extension agents to build (see Table 6), followed by County Extension Directors, Mentors, and Extension Specialists/researchers. 


\section{Table 6}

Ranking of Important Contacts from the Agent Relationships Domain

\begin{tabular}{lcc}
\hline Competency & $\begin{array}{c}\text { Ranking of } \\
\text { importance }\end{array}$ & $\begin{array}{c}\text { Average } \\
\text { ranking }\end{array}$ \\
\hline Clientele & 1 & 2.37 \\
Agent to Agent & 2 & 2.53 \\
County Extension Directors & 3 & 3.15 \\
Mentors & 4 & 3.40 \\
Extension Specialists/Researchers & 5 & 3.55 \\
\hline
\end{tabular}

Regarding the competency domains of Technical Resources and Personal Relationships, there was little agreement between respondents on what the highest priorities were. Some competencies that occurred with a lower frequency on the first survey, such as public speaking/presentation skills, were some of the higher priority competencies ranked by respondents of the second survey. The differentiation in responses between the two surveys illustrates the difficult nature of open-ended questions and further exemplifies why a second quantitative survey was necessary to determine priority needs.

\section{Conclusions, Discussion, and Recommendations}

Early-career Extension agents enter the organization with a wide array of formal education backgrounds (Benge et al., 2020). This breadth of employee competencies and skillsets increases the intellectual capacity of the Extension organization as a whole. However, it can be difficult to create a baseline knowledge in Extension workforce that meets the needs of all new agricultural agents. This is a major challenge when developing an effective onboarding program, especially considering that many agricultural agents have multiple responsibilities within their counties and need to be trained in multiple commodities (Rasmussen, 1989; Seevers \& Graham, 2012).

The surveys were only sent to agriculture/horticulture agents and CEDs, and the questions were framed to ask what new agricultural agents needed specifically; therefore, the respondents may have been in a certain frame of mind regarding agriculture specific competencies. General Extension skills such as program development and design were identified by previous studies as critical training needs (Cooper \& Graham, 2001; Harder et. al., 2010). However, the survey participants for this study did not rank these needs most important. This does not mean these competencies are not important as they still occurred frequently in the initial survey, but may instead be an indicator that these needs are being met either by the already occurring Extension Faculty Development Academy or by the mentorship from experienced agents. Another explanation for some general Extension skills having a lower priority may be based on the different perceptions of what a new agent should be focusing on in their early-career days. Our study identified the priority needs of new agricultural Extension agents as an important step in developing an onboarding program that establishes a level of standard knowledge. 
Those findings will serve to enhance the EFDA to cover critical needs within the pre-entry and entry levels within the Extension Professional Development Model (Benge et al., 2011). Ensuring each new agent begins their career with at least the same baseline of knowledge will also help future professional development opportunities (in-service trainings) since instructors will know what to expect in terms of basic skills. A strong career start (Benge et al., 2011) through a more complete new Extension agent training experience will lead to long-term career success for agriculture Extension agents (Harder et al., 2010).

Next steps for ensuring career success is to implement an onboarding process that fulfills the need of the identified priority competencies. Given the breadth of answers and priorities identified, it is unlikely a singular training will suffice for matching the needs of all agriculture Extension agents. A tiered approach where a logical sequence of trainings builds up on precedents, and where initial sections are common for all agricultural agents might be an efficient strategy. As trainees advance in knowledge, they progress into more focused, management-oriented sections within their specific job-related content areas. The development of a proper training will require further research of how to instruct new Extension agents in the most effective manner. Research should focus on how to disseminate the general conceptual knowledge to agricultural Extension agents with a broad range of responsibilities and programmatic areas in order to effectively prepare agents for the duties expected of them.

\section{References}

Arnold, S., \& Place, N. (2010). Career influences of agricultural extension agents. Journal of Agricultural Education, 51(1), 11-21. https://doi.org/10.5032/jae.2010.01011

Ary, D., Jacobs, L. C., Razavieh, A., \& Sorensen, C. (2006). Introduction to research in education (7th ed.). Wadsworth Publishing.

Bailey, J. A. (2005). Perceptions and impacts of the University of Florida, Institute of Food and Agricultural Science (UF/IFAS) Extension mentoring program (Master's thesis). https://ufdc.ufl.edu/UFE0011830/00001

Benge, M., Harder, A., \& Carter, H. (2011). Necessary pre-entry competencies as perceived by Florida Extension agents. Journal of Extension, 49(5). https://www.joe.org/joe/2011october/a2.php

Benge, M., Harder, A. \& Goodwin, J. (2015). Solutions to burnout and retention as perceived by county Extension agents of the Colorado University Extension system. Journal of Human Sciences and Extension, 3(1), 1-16. https://www.jhseonline.com/article/view/606

Benge, M., Martini, X., Diepenbrock, L. M., \& Smith, H. A. (2020). Determining the professional development needs of Florida integrated pest management Extension agents. Journal of Extension, 58(6). https://www.joe.org/joe/2020december/rb5.php 
Brown, A. S., Gibson, J. D., \& Stewart, D. L. (2008). An assessment of Virginia Cooperative Extension's new agent training program. Journal of Extension, 46(4). https://www.joe.org/joe/2008august/a7.php

Cooper, A. W., \& Graham, D. L. (2001). Competencies needed to be successful county agents and county supervisors. Journal of Extension, 39(1). https://www.joe.org/joe/2001 february/rb3.php

Diaz, J. M., Jayaratne, K. S. U., \& Chaudhary, A. K. (2020). Evaluation competencies and challenges faced by early career extension professionals: Developing a competency model through consensus building. Journal of Agricultural Education and Extension, 26(2), 183-201. https://doi.org/10.1080/1389224X.2019.1671204

Dillman, D. A., Smyth, J. D., \& Christian, L. M. (2009). Internet, mail, and mixed-mode surveys: The tailored design method (3rd ed.). Wiley.

Florida Department of Agriculture and Consumer Services. (2019). Florida agriculture overview and statistics. https://www.fdacs.gov/Agriculture-Industry/Florida-AgricultureOverview-and-Statistics

Gentry, M., Edgar, L. D., Graham, D. L., \& Kirkpatrick, T. (2017). Assessing Extension agents' nematology knowledge needs and related resource preferences: Implications for trainings on complex agricultural topics. Journal of Extension, 55(1). https://www.joe.org/joe/2017february/a5.php

Gusto, C., Silvert, C., Diaz, J., Carton de Grammont, P., \& Coyle, D. (2020). Identifying forest health gaps: A needs assessment of tree and forest health Extension education. Journal of Extension, 58(1). https://joe.org/joe/2020february/rb3.php

Harder, A., Place, N. T., \& Scheer, S. D. (2010). Towards a competency-based Extension education curriculum: A Delphi study. Journal of Agricultural Education, 51(3), 44-52. https://doi.org/doi:10.5032/jae.2010.03044

Kilonzo-Nthenge, A., Ricketts, J. C., \& Pitchay, D. (2018). Good agricultural practices training for limited-resource produce growers and Extension educators. Journal of Extension, 56(7). https://www.joe.org/joe/2018december/rb5.php

Lincoln, Y. S., \& Guba, E. G. (1985). Naturalistic inquiry. SAGE.

McClelland, D. (1973). Testing for competence rather than intelligence. American Psychologist, 28(1), 1-14. https://pubmed.ncbi.nlm.nih.gov/4684069/ 
Merriam, S. B. (1998). Qualitative research and case study applications in education. JosseyBass.

Moore, L. L., \& Rudd, R. D. (2004). Leadership skills and competencies for Extension directors and administrators. Journal of Agricultural Education, 45(3), 22-33. https://doi.org/10.5032/jae.2004.03022

Patton, M. Q. (1999). Enhancing the quality and credibility of qualitative analysis. Health Sciences Research, 34(5 part 2), 1189-1208. https://www.ncbi.nlm.nih.gov/pmc/articles/PMC1089059/pdf/hsresearch000220112.pdf

Rasmussen, W. D. (1989). Taking the university to the people: Seventy-five years of Cooperative Extension. lowa State University Press.

Schwarz, M. H., \& Gibson, J. (2010). A needs assessment of aquaculture Extension agents, specialists, and program administrators in Extension programming. Journal of Extension, 48(2). https://www.joe.org/joe/2010april/pdf/JOE v48 2a6.pdf

Seevers, B., \& Graham, D. (2012). Education through Cooperative Extension (3rd ed.). University of Arkansas.

Witkin, B. R., \& Altschuld, J. W. (1995) Planning and conducting needs assessments: A practical guide. SAGE.

(C) 2021 by authors. This article is an open access article distributed under the terms and conditions of the Creative Commons Attribution license (http://creativecommons.org/licenses/by/4.0/). 